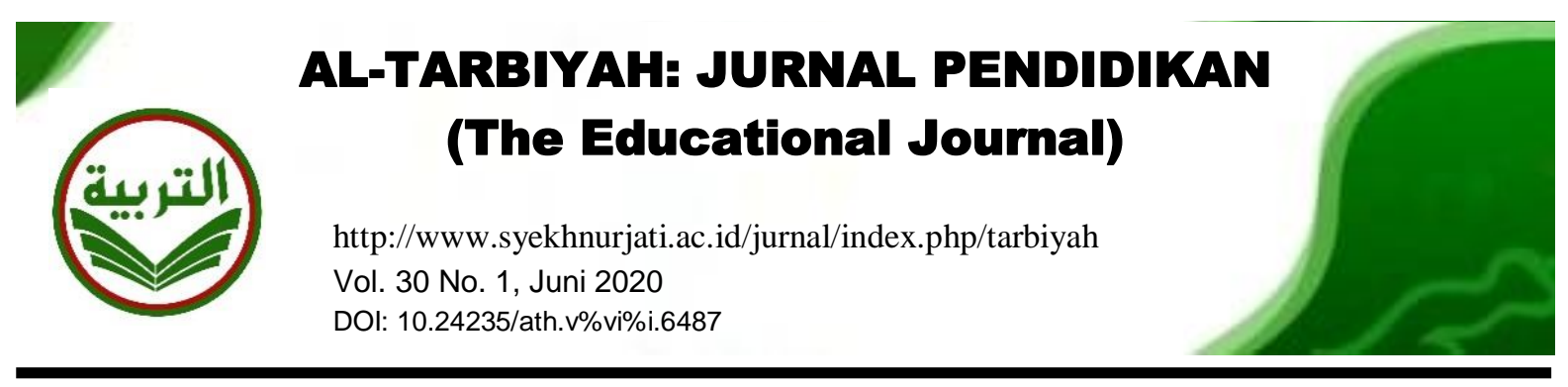

\title{
SCAFFOLDING IN TEACHING WRITING
}

\author{
Listiana Ikawati \\ Tadris Bahasa Inggris, IAIN Syekh Nurjati Cirebon \\ e-mail: listianaikawati85@gmail.com
}

\begin{abstract}
As one of the prominent skills in English language learning, mastering writing is a must for students at various educational levels, yet many of them sometimes have difficulties in generating ideas, using grammar and vocabularies and maintaining unified ideas in their writing. Considering the problems faced by the students and practices needed by students to improve their writing skills, the teachers can use scaffolding strategy derived from Vygostky's ZPD theory. It is believed that students can complete the difficult task that is a bit higher than their ability through guidance from more expert others. The purpose of the study was to figure out how scaffolding can be used to improve students' writing skills. The results of the study show that scaffolding can be used as teacher's strategy to improve students' writing skills by integrating the writing process in the genre-based approach representing the scaffolding. It shows how the teacher gradually removes his assistance as soon as students have the experience for completing the task. Through scaffolding, students will learn how to experience the strategy, rather than merely to complete the task and it leads them to be autonomous and successful writers.
\end{abstract}

Keywords: Scaffolding, writing, and ZPD

\section{INTRODUCTION}

The goal of learning a language is to be able to communicate fluently and accurately using the target language both in spoken and written forms. Therefore, the students are not only required to be able to speak English fluently, but also to express their ideas and feelings in written form. However, some students consider writing their ideas down as an uneasy thing. Some also add that it is more complex than speaking, since the goal of speaking is to share information between the speaker and the listener. Thus, sometimes people think that as long as their listeners can understand what they are saying or the messages can be delivered well, they think that their goals are achieved without considering the forms. On the other hand, in writing, not only the messages are important, but also the accuracy. In order to achieve this goal, students need to have sufficient skills.

Developing students' skills cannot be separated from the prominent role of teachers. Learning activities which were teacher-centered in the past have shifted into student-centered learning. In this learning atmosphere, students will get more chance to engage in the teaching and the 
learning process and therefore be able to improve their skills. This requires teachers to change their views that they are the main and only sources of the teaching and learning process and the students are merely passive receivers of knowledge. Instead, they should regard themselves as the designers and facilitators of the teaching and learning process.

This idea is supported by Harmer's theory (as cited in Naibaho, 2019) who points out nine teacher's roles in the teaching and learning process including: (1) teacher as a controller, (2) teacher as an organizer, teacher as an assessor, (3) teacher as a prompter, (4) teacher as a participant, (5) teacher as a resource, (6) teacher as a tutor, (7) teacher as a observer, (8) teacher as a performer, and (9) teacher as a teaching aid. As a controller, a teacher is expected to be able to control class activities and give appropriate instructions for the activities. As an organizer, a teacher must be able to organize various classroom activities and get students engaged in the activities effectively. Teacher's role as an assessor requires him or her to assess students' performance and provide feedback for students' mistakes and errors. A teacher also plays a role as a prompter which means that in classroom activities, he or she sometimes needs to give prompts or clues when students get stuck in finding ideas or answering certain questions. This can be done by, for instance, mentioning the initial letter of a certain word which students are trying to remember. A teacher can also be a participant who takes part in the activities designed for the students. Participating in classroom activities will create a more enjoyable atmosphere for the students because they can feel the togetherness with the teacher. The teacher can also feel the dynamic atmosphere of the classroom activities and be more sensitive about students' abilities and difficulties.

In addition, a teacher must be able to become a resource for students learning. The teacher must be able to provide information needed by the students or be available for them when they need some clarification about what they have learnt by themselves. In group projects, a teacher can play a role as a tutor by working with each group to guide their task completion. Meanwhile, the teacher can also be an observer who monitors students' learning and takes notes on students' progress and difficulties for feedback. Teacher's role as a performer requires the teacher to be able to enthusiastically, clearly, and accurately act out certain skills or activities which have been mastered by the students. Thus, teacher works as a role model for students' learning. Finally, a teacher can also be a teaching aid who provides comprehensible and meaningful learning input for students.

Instead of performing one of those roles exclusively, teachers had better be able to perform each of those roles simultaneously in the teaching and learning process because preferring on a particular role only will not be effective for both students and the teachers. For example, if a teacher is being a resource, she or he will be definitely exhausted during the whole teaching and learning process and students will not be motivated to learn because the class atmosphere will be teacher-centered as if students have no chance to actualize themselves. This will definitely make students too dependent on the teacher and inhibit them from being autonomous. When the teacher knows when he or she should play certain roles as a controller, a resource, 
and a participant, for instance, he or she will help students to be autonomous learners.

According to Palfreyman and Smith (2003, as cited in Masouleh \& Jooneghani, 2012), autonomy can be considered as a 'human right' which is more effective than other learning approaches and it obliges students to be responsible to their own learning by making use of accessible resources, particularly those outside the classroom. Additionally, Dam (1995, as cited in Borg and Al-Busaidi, 2012) emphasizes that the key notion of learner autonomy involves 'willingness' which means that students will not be considered as autonomous learners unless they are willing to 'take charge' of their own learning. In other words, autonomous learners are those who are willing to use the obtainable resources to be responsible and to control their own learning progress.

In line with the definitions of autonomous learners above, Naiman et al. (as cited in Hendar, 2014) proposes seven characteristics of good language learners which include: (1) ability to find out their suitable learning styles, (2) active involvement in the learning process, (3) ability to discover how the language works, (4) knowledge on the use of language for communication, (5) ability similar to 'good detectives', e.g. finding clues, making guesses, (6) ability 'to learn to think in the target language', and (7) understanding that learning a language is uneasy and ability to find ways to avoid being frustrated and not confident in the learning process. It can be seen that the role of the teaching and learning process is not only to make students acquire such language abilities to make them be able to communicate effectively in the teaching and learning process, but also to make them be willing to assess their own learning, identify their own learning obstacles, and figure out ways to deal with the difficulties so that they can be successful language learners.

Furthermore, writing should be regarded as a challenge rather than a problem inhibiting students to write. The challenge is important since it what derives students' motivation to write. Then, it is the responsibility of the teacher to apply a strategy to help them solve the challenge. In this case, scaffolding comes as a solution to help students deal with the challenge by providing them with the help of more experienced people and training them to further independently solve other similar challenges. Scaffolding will also train students to be autonomous because before they are ready and confident enough to take full charge of their learning, they need guidance from the teacher.

Some research has been conducted to know the benefits of scaffolding in teaching writing. The first is a study conducted by Padmadewi and Artini (2018) entitled "Using Scaffolding Strategies in Teaching Writing for Improving Students in Primary School." This study aimed at analyzing the implementation of scaffolding activities in teaching writing to improve the literacy of elementary school students. The results of the study show that (1) the teachers employed various scaffolding strategies to improve students' English literacy, (2) scaffolding improves not only students' writing quality but also students' attitude and interests in writing, and (3) scaffolding contributes to students' writing competency. Second, Veerapan et al., (2011) carried out a study entitled "The Effect of Scaffolding Technique in Journal Writing among the Second Language Learners." The purpose of the study was to 
know how second language learners acquire the use of English language through journal writing. The result of the study reveals that scaffolding helps students overcome their problems in writing and effectively develops their journal writing. The third study was done by Faraj (2015). The title of the study was "Scaffolding EFL Students" Writing through the Writing Process Approach", which had the purpose of presenting the effect of scaffolding on EFL students' writing ability through the writing process. The results of the study show that (1) students' achievement in the-post-test is significantly improved compared to the pretest achievement, (2) scaffolding students writing through the writing process approach is suitable to the students' writing needs, and (3) scaffolding makes students become more confident to share their ideas through their writings. From those previous studies, it can be seen that the benefits of scaffolding in wiring in unquestionably great and worth-trying.

This research focuses on how scaffolding strategy can be used to improve students' writing skills. It mainly tries to answer three main questions namely, what scaffolding is, why scaffolding is needed and how scaffolding can be implemented in teaching writing.

\section{RESEARCH METHOD}

This research used a library research method. Library research is a type of research method which studies literature as its object of the study (Sawarjuwono \& Kadir, 2003) "Library research involves the step-by-step process used to gather information in order to write a paper, create a presentation, or complete a project." (Elmer, E. Rasmuson Library, 2018). In this research, step-by-step process was also done to gather some literature related to the topic of the study. Theories from various sources related to scaffolding in teaching writing were used to provide answers for the research questions of the study. To obtain the theories needed, books, journal articles and documents were collected. The data analysis was done by using descriptive qualitative technique.

\section{RESULT AND DISCUSSION}

To explain the concept of scaffolding in a simpler term, how a cook teaches his cook helper to cook spaghetti can be a good example. First, the cook will show the cook helper the ingredients, the tools and also the steps on how to make it by observing the way he cooks. Later, he will ask her to help him chop the vegetables or to stir it while cooking with little guidance from him. Finally, after she knows the ingredients, tools and cooking steps, she will cook her own spaghetti. From that example, it can be seen that there is a gradual release of support from the watching stage to the independent cooking stage. That is what scaffolding is.

Some experts have defined scaffolding in various definitions for many years. One of them is from Verhagen and Collis (1996, as cited in Alake and Ogunseemi, 2013) who state that scaffolding is a temporary support provided for students' learning until the students can perform the support independently. In line with that, Wood et al., (1976, as cited in Bodrova and Leong, 1998) define scaffolding as specific kinds of assistance enabling students to function at higher levels of their zones of proximal development (ZPD). Brunner (as cited in Bodrova and Leong 1998) also adds that teacher's scaffolds do not make the task easier, but it makes it possible for students to complete it with support. It can be 
concluded that scaffolding is a strategy used by teachers to give assistance to students and there is a gradual release of responsibility during the teaching and learning process until the students can finally complete the task independently.

Applying scaffolding in all educational settings is needed in order to achieve two basic goals: (1) accomplishing the task, and (2) learning from one's efforts, that is, improving one's performance on the future tasks in the process (Reiser, 2004). Thus, the aim of teacher's assistance is not only to help students complete the task, but rather to let them experience the strategies used to work on certain task and later to be able to apply those strategies without assistance.
As it has been mentioned above, the goal of scaffolding is to complete the task at the higher level of students' ZPD. The notion of ZPD was first used by Vygotsky. Vygotsky (as cited in Vonna, 2015) defines ZPD as "the distance between the actual development level of the learner, as determined by independent problem solving, and the level of potential development, as determined through problem solving under teacher guidance and/or interaction and collaboration with more capable peers". The following figures will show how the role of teacher's or peer's assistance can help students function optimally in their ZPD to complete the difficult task and how the scaffolding (assistance in a ZPD) will become the foundation to activate further ZPDs.

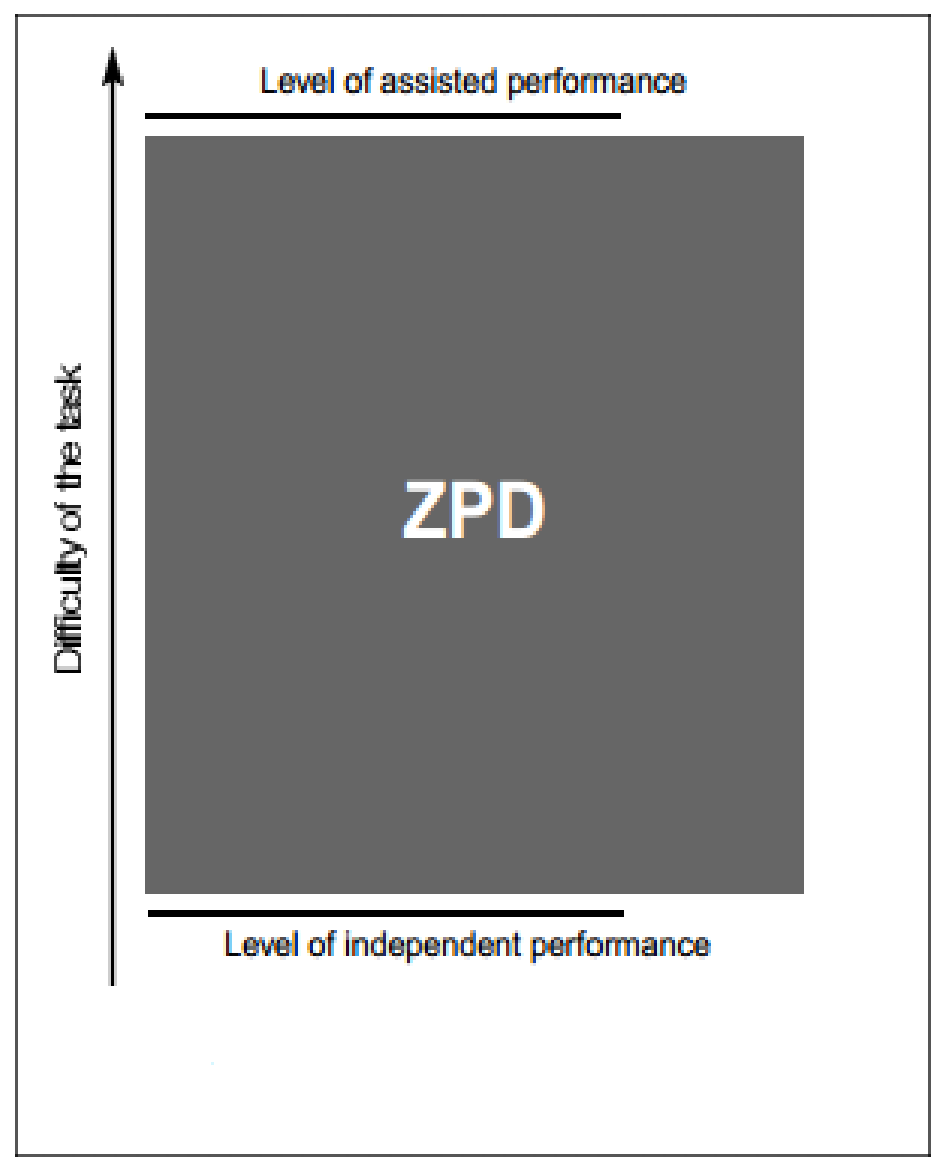

Figure 1. ZPD adopted from Bodrova \& Leong (1998) 


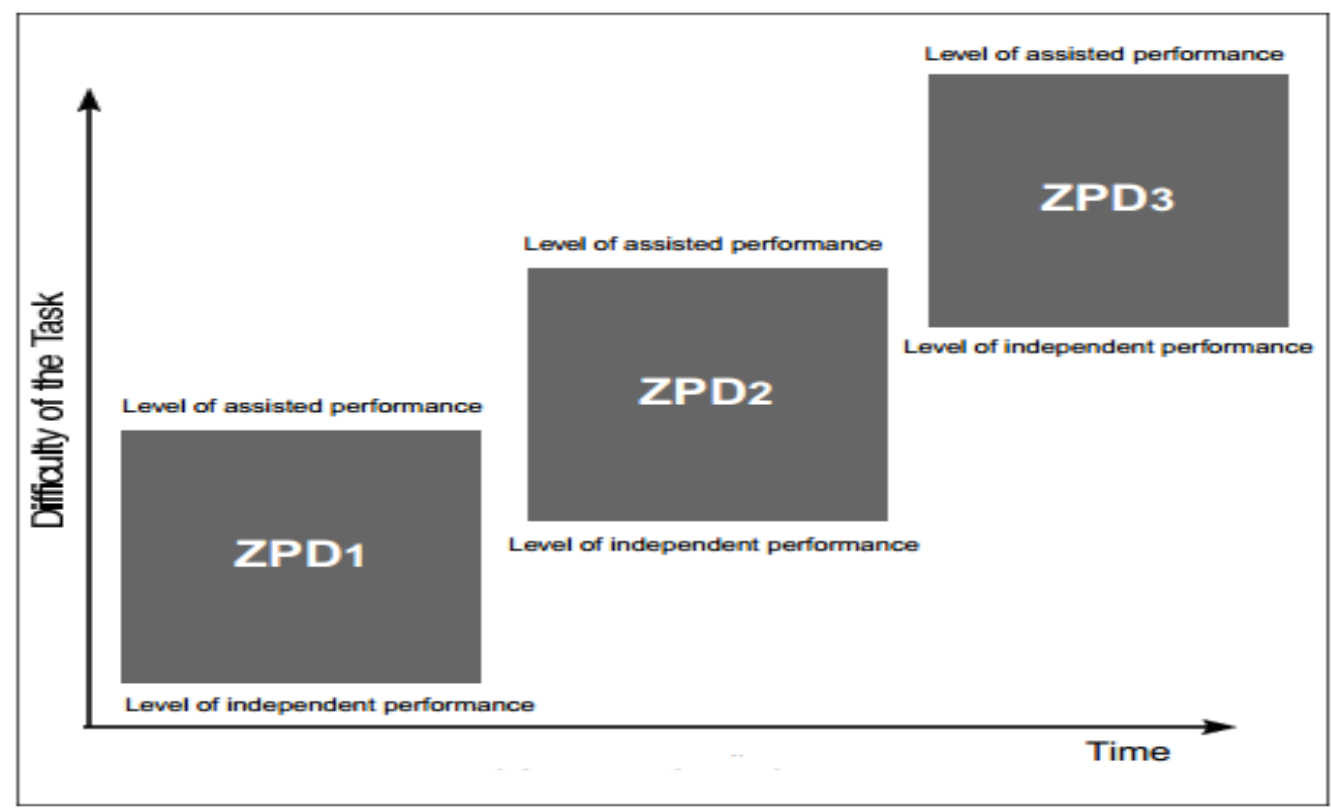

Figure 2. Changes in a child's ZPD adopted from Bodrova \& Leong (1998)

From figure 1, it is illustrated that the assistance from the teacher or interaction with more expert peers can enable students to operate their optimum ZPD to complete the difficult task independently. From figure 2, it can be assumed that learning is a scaffolded process. The teacher scaffolds students' learning in order to activate their ZPD and the development of one ZPD will become the scaffolding basis for the next ZPDs.

Therefore, the teacher's understanding and ability to condition himself or herself to play certain roles simultaneously in the teaching and learning process is encouraged. If following the ZPD's assisting stage, the teacher should know that in the beginning of the lesson he or she might be a designer, a controller and a resource by providing explanation to the students. Later, the teacher will play roles as a participant and an observer by reducing his or her assistance to students learning. Finally, when students are believed to be able to master the knowledge given and are confident enough to perform their ability, the teacher will be an assessor who assess students' ability and gives necessary feedback.

The whole scaffolding process will later train students to gradually be autonomous learners possessing the characteristics of good language learners as proposed by Naiman et al. in Hendar (2014). Students will have ability to figure out their learning obstacles and find ways to overcome them, ability to figure out the appropriate learning styles supporting their learning, ability to actively engaged in the teaching and learning process, ability to be risk takers who make guessing in their learning, ability to think in the target language, knowledge on how language functions and the use of language for communication. By the end of the learning process, the students will be independent learners who can communicate in the target language confidently and effectively. This process is achieved through scaffolding.

There are many kinds of scaffoldings, such as conceptual scaffolding, contingent scaffolding, reciprocal scaffolding, mutual 
scaffolding, technical scaffolding, and scaffolded writing (Schwieter, 2010). This paper will especially concern with the use of scaffolding in writing (scaffolded writing).

The use of scaffolding in writing was inspired by Elkonin and Galperin applied for self-generated messages of young writers (Bodrova \& Leong, 1998). The scaffolded writing method employs two techniques: materialization and private speech. The former deals with the use of tangible objects and physical actions to explain a certain concept, while the latter is a self-directed speech. Both techniques involve teachers' assistance with gradual responsibility removed.

Roehler and Cantlon (1997, as cited in Bikmaz et al., 2010) propose five scaffolding strategies used by teachers as follows:

1. offering explanation (giving students explicit explanation to build students' understanding);

2. inviting student participation (involving students in the process);

3. verifying and clarifying students understanding (checking students' understanding);

4. modelling of desired behavior: (teaching behavior on how students should feel, think and act in a given situation); and

5. inviting students to contribute clues (motivating students to give strategies on how to complete the task).

\section{The reasons for using scaffolding}

Writing is one of the four main skills in English language learning which has a prominent role in communication. Through writing, students can communicate their feelings, ideas and thoughts. Suleiman (2000, as cited in Hosseini et al., 2013) points out that "writing is a central element of language, any reading and language arts program must consider the multidimensional nature of writing in instructional practices, assessment procedures, and language development." It shows how significant the role of writing is in the process of language development and how great the influence of writing in students' lives.

Still, some students find it uneasy to write something. It requires students to follow the complex cycle of writing including prewriting, drafting, revising, editing, and publishing. Those involve good skills of vocabulary, grammar, punctuation and ability to maintain the coherence and cohesion of the sentences, yet students even have problems in generating ideas to write. These are what inhibit them to write fluently.

Therefore, teachers need to provide students with supports in their writing process. The tasks provided by teachers should be considered a little bit more difficult than students' current ability, so that the learning process can be meaningful by activating the higher level of their ZPD. By doing so, students will find the tasks as challenges that can be completed with supports from the teacher. However, it must be understood that teachers' supports here should be considered as temporary ones which lead students to be able to perform other tasks independently in the future. In this case, scaffolding allows students to complete high challenges with high supports giving meaningful learning experience for students. Below is the scaffolding model proposed by Mariani (1997, as cited in Wilson, 2014) showing the importance of high challenge and high support for students' learning. 


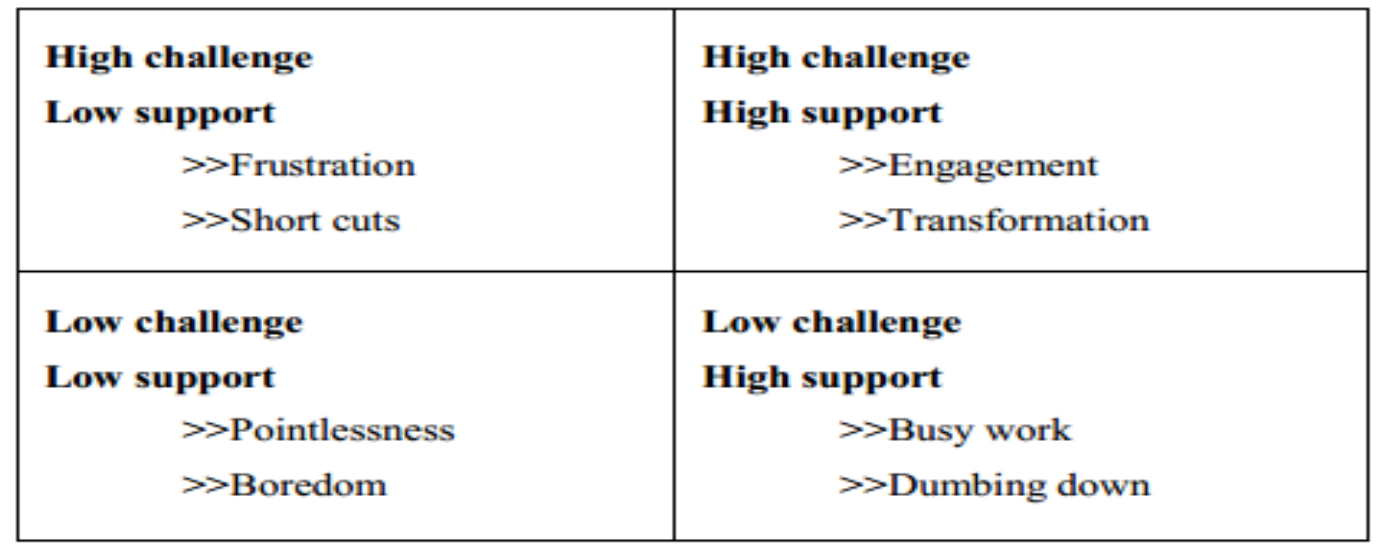

Figure 3. Mariani's 'High Challenge High Support' Model adopted from Wilson (2013)

The figure above shows that the amount of challenge and support given by the teacher gives various effects to the students which can be mainly classified into four. When the teacher gives a low challenge with low support, students will feel bored and the task is useless. When the teacher gives a high challenge with low support, students will feel frustrated and may do some short cuts by, for example, copying their friends' work or doing plagiarism. A low challenge with high support will result in giving the teacher busy work and gradually dumbing down students' ability. Finally, engagement and transformation may result from a high challenge given by the teacher but it is also supported by high support. The high challenge with the high support is realised in the implementation of scaffolding.

\section{The procedure of applying scaffolding in writing}

Considering the importance and effectiveness of scaffolding to improve students' writing skills, this study proposes the implementation of scaffolding by integrating the writing process in Genrebased approach proposed by Gibbons (2002). This approach is chosen since it has similar goal with scaffolding and represents the step-by-step guide provided in scaffolding. Emilia (2016) in her book entitled "Pendekatan Berbasis Teks" stresses that the genre-based approach of systemic functional grammar has similar principles to scaffolding and ZPD which guide students under an apprenticeship framework. In the learning process, students play a role as trainees and the teacher becomes the trainer (the expert) whose purpose is to successfully guide students to learn the language.

Feez (as cited in Liang, 2007) proposes a five-stage teaching-learning cycle, including building the context, modeling and deconstructing the text, joint construction of the text, independent construction of the text, and linking related texts. Gibbons (2002, as cited in Dewi, 2013) also proposes a similar curriculum of the genre-based approach in teaching writing involving building the field, modeling the text type, joint construction, and independent writing.

The writing process will be integrated to the model of genre-based approach proposed by Gibbons (2002). This procedure will outline the framework of teaching a procedure text. 
1. In building knowledge of the field stage, the teacher tries to relate students' prior knowledge and experience by asking about the topic (e.g. procedure text). For example, the teacher asks students some questions like, 'Do you like fried rice?', 'Do you know how to make it?' In this stage the teacher holds $100 \%$ of the responsibility. In other words, the teacher provides high support and little control for students' learning

2. In modelling the text, the teacher gives a model text to students and together with students deconstruct the generic structure and language features of the text. For instance, in a procedure text, the generic structure consists of goal, material and step and the language features of the text involve the use of simple present, imperatives, sequencing transition words, and adjectives. Teacher's responsibility in this stage is about $90 \%$. The teacher gives moderate support and low control.

3. The third stage, joint construction, involves the checking of students' understanding after they build their schemata about the procedure text. This is done by asking students to do some practices collaboratively. First, the teacher can ask students to do fill-inthe-blank exercise requiring them to complete it with vocabularies in the form of imperative verbs and sequencing transition words. Second, the teacher asks students to arrange jumbled sentences into orderly procedure paragraphs. Finally, students are grouped and are asked to make a recipe based on the main ingredients given by the teacher. In this stage the process of writing is started. This will show gradual release of teacher's responsibility from $90 \%-40 \%$. The teacher starts giving low support and moderate control.

How the writing process takes place is described as follows. In prewriting stage, students have to decide the topic by determining the name of the dish. In drafting, students begin to make the draft of the recipe collaboratively. After the draft is done, they exchange their draft with another group. Here, the peer feedback will be applied in revising. Each group has to correct another group's draft and the teacher should check the corrections given to make sure about the accuracy. It shows how the support of more expert others can be derived not only form the teachers but also from peers. Then, students will move to the editing stage by rewriting the draft based on the feedback. Finally, the students will publish their writing. It is not necessarily published in the paper form, it can also be published in the learning blog or presentation in front of the class.

4. The last stage is independent construction. Through their experience in constructing the text before, they later have to construct the procedure text individually and submit it to the teacher. In this last stage, teachers' responsibility is about $10 \%$ only, or even $100 \%$ responsibility is on the students themselves. The teacher only gives little support but high control to students.

\section{CONCLUSION}

Writing is an important means for communicating one's ideas, feelings and thoughts. However, the complex process and requirements in writing make students reluctant to write. To solve these problems, 
scaffolding can be used as a strategy to give students temporary supports to complete the tasks and apply their experience to complete the next tasks without assistance. Since the goal of scaffolding is the gradual release of responsibility from teachers to students, the strategy can be applied in writing by integrating the writing process in the genre-based approach. This strategy can give a step-by-step guide for students to be independent writers and it can be applied in all levels of students' proficiency, but it will be more helpful for young learners or beginner learners. Last but not least, the nature of learning is basically a scaffolded process which enables students to move from one ZPD to another in the process of learning the language and acquiring new knowledge.

\section{REFERENCES}

Alake, E.M. \& Ogunseemi, O. E. (2013). Effects of Scaffolding Strategy on Learners' Academic Achievement in Integrated Science at the Junior Secondary School Level. European Scientific Journal, 9(19), 149-155.

Bikmaz, F.H., et. al. (2010). Scaffolding Strategies Applied by Student Teachers to Teach Mathematics. The International Journal of Research in Teacher Education, 1 (special issue), 25-36.

Borg, S. \& Al-Busaidi, S. (2012). Learner Autonomy: English Language Teachers' Beliefs and Practices. ELT Research Paper available online on www.britishcouncil.org, Retrieved on 1 May 2020 at 11.27 a.m.

Bodrova, E. \& Leong D. J. (1998). Scaffolding Emergent Writing in the Zone of Proximal
Development. Literacy Teaching and Learning. 3(2), 1-18.

Dewi, M. S. N. (2013). Scaffolding Provided by a Teacher in Teaching Writing News Item Text. Journal of English and Education, 1(2), 31-38.

Elmer E. Rasmuson Library. (2018) August

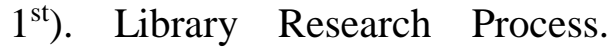
Elmer E. Rasmuson Library. https://library.uaf.edu/ls101research-process.

Emilia, E. (2016). Pendekatan Berbasis Teks. Bandung: PT. Kiblat Buku Utama.

Faraj, A. K. A. (2015). Scaffolding EFL Students Writing through the Writing Process Approach. Journal of Education and Practice. 6(13), 131-141.

Hendar. (2014). Implementing Nunan's Autonomous Language Learning Model (Nallm) to EFL Students of Widyatama University. An online document published by Professional development in education, Retrieved on 2 May 2020 at 1 p.m. from http://simpen.lppm.ut.ac.id/Internas ional\%20Seminar/014.\%20\%20He ndar_Implementing $\% 20 \% 20$ Nunan $\%$ E2\%80\%99s\%20Autonomous\%2 0Language\%20Learning\%20Model .pdf

Hosseini, M., et. al. (2013). In the Importance of EFL Learner's Writing Skill: Is there any Relation between Writing Skill and Content Score of English Essay Test? International Letters of Social and Humanistic Sciences, 6, 1-12.

Liang, J. (2007). Language Scaffolding in Second Language Writing. The CATESOL Journa, 19 (1), 71-88.

Masouleh, N.S., \& Jooneghani, R.B. (2012) Autonomous Learning: A teacherless learning! An article presented on 
International Conference on New Howizons in Education 2012, ScienceDirect, 55, 835-842.

Naibaho, L. (2019). Teacher's Roles on English Language Teaching: A Students Centered Learning Approach, International Journal of Research -Granthaalayah, 7(4), 206-212.

Padmadewi, N. Y. \& Artini, L.P. (2018). Uisng Scaffolding Strategies in Teaching Writing for Improving Student Literacy in Primary School. Advances in Social Science, Education and Humanities Research, (178), 156-160.

Reiser, B. J. (2004). Scaffolding Complex Learning: The Mechanism of Structuring and Problematizing Student Work. The Journal of the Learning Sciences, 13(3), 273-304.

Sawarjuwono, T. \& Kadir, A.P. (2003). Intellectual Capital: Perlakuan Pengukuran dan Pelaporan (Sebuah Library Research). Jurnal Ekonomi Akuntansi, Fakultas EkonomiUniversitas Kristen Petra, 5(1), 3557.
Schwieter, J. W. (2010). Developing Second Language Writing through Scaffolding in the ZPD: A Magazine Project for an Authentic Audience. Journal of College Teaching and Learning. 7 (10), 3146.

Veerapan, V., Suan, W.H., \& Sulaiman, T. (2011). The Effect of Scaffolding Technique in Journal Writing among the Second Language Learners. Journal of Language Teaching and Research, 2(4), 934940.

Vonna, Y., Mukminatien, N., \& Ekaning, D. L. (2015). The Effects of Scaffolding Techniques on Students' Writing Achievement. Jurnal Pendidikan Humaniora. 3(1), 227-233.

Wilson, K. (2014). Scaffolding Theory: High Challenge, High Support in Academic Language Learning (ALL) Contexts. Journal of Academic Language \& Learning, 8(3), 91-A100. 